\title{
Pola Komunikasi Dakwah Bil Hal Muhammadiyah pada Masyarakat Agraris
}

\author{
Euis Evi Puspitasari ${ }^{a, 1,{ }^{, *}}$ dan Utan Sahiro Ritonga ${ }^{\mathrm{b}, 2}$ \\ a,bUniversitas Muhammadiyah Bandung \\ E-mail: 'euis.syarif16@gmail.com*dan²utanritonga@umbandung.ac.id \\ *corresponding author
}

\section{Keywords:}

communication patterns, islamic mass organization, da'wah bil hal, agrarian society

\section{Kata Kunci:}

pola komunikasi, organisasi massa islam, dakwah bil hal, masyarakat agraris

\begin{abstract}
Not only oral (tabligh, oral, and written) da'wah that can be done to touch certain communities such as the farming community, but also the planned dakwah bil hal (da'wah with action). Dakwah bil hal requires a communication pattern so that various activities planned in the program can be carried out following the expectations of the parties involved. By using qualitative descriptive methods and interactive model data analysis techniques. It is known that there are four communication patterns implemented by Muhammadiyah administrators in Bandung Regency including interpersonal communication patterns, group communication, public communication, and mass communication. Interpersonal communication patterns and group communication patterns are the most effective communication used in the implementation of preaching when it comes to Muhammadiyah.
\end{abstract}

\begin{abstract}
ABSTRAK
Tidak hanya dakwah bil lisan (tabligh, lisan dan tulisan) yang dapat dilakukan untuk menyentuh komunitas tertentu seperti komunitas petani, tetapi juga dakwah bil hal (dakwah dengan tindakan) yang terencana. Dakwah bil hal ini pada kenyataannya membutuhkan sebuah pola komunikasi agar berbagai kegiatan terencana dalam program dapat terlaksana sesuai dengan harapan pihak-pihak terlibat. Dengan menggunakan metode deskriptif kualitatif dan teknik analisis data model interaktif diketahui bahwa terdapat empat pola komunikasi yang diterapkan oleh pengurus Muhammadiyah di Kabupaten Bandung meliputi, pola komunikasi antar pribadi, komunikasi kelompok, komunikasi publik, dan komunikasi massa. Pola komunikasi antarpribadi dan pola komunikasi kelompok merupakan komunikasi yang paling efektif digunakan dalam pelaksanaan dakwah bil hal Muhammadiyah
\end{abstract}

Copyright $(\odot 2020$ Channel Jurnal Komunikasi. All right reserved.

\section{PENDAHULUAN}

Organisasi keagamaan yang menghimpun masyarakat sudah lama ada dan tumbuh berkembang di Indonesia. Keberadaaan organisasi massa ini merupakan dinamika dari sebuah proses kehidupan yang ditandai dengan adanya gerakan dan perubahan sosial. Perubahan sosial tentu saja tidak serta merta terjadi, tetapi direncanakan dan diarahkan. Ada agen perubahan yang merencanakan dan mengarahkan yang disebut sebagai birokrasi. Birokrasi terbagi menjadi dua yaitu birokrasi publik yang beraktivitas dalam struktur pemerintahan dan birokrasi privat yang beraktivitas dalam kehidupan organisasi swasta seperti LSM, dan kelompok-kelompok dalam masyarakat (Mulyadi, 2015). Birokrasi inilah yang memodifikasi sikap dan tingkah laku individu atau kelompok yang dijadikan sasaran perubahan dengan cara memperkenalkan ide-ide baru atau mengadakan inovasi ke dalam sistem sosial untuk mencapai tujuan yang direncanakan.

Salah satu birokrasi privat yang merupakan organisasi swasta berbasis keagamaan khususnya organisasi massa Islam adalah Muhammadiyah. Muhammadiyah dipandang memiliki peranan yang sangat penting dalam menyebarkan ide-ide pembaharuan Islam dan memiliki pengaruh yang sangat kuat di kalangan masyarakat menengah Indonesia. Muhammadiyah dapat dikatakan trendsetter dan dapat diibaratkan sebagai lokomotif penarik gerbong gerakan reformis 
Indonesia (Yusra, 2018). Muhammadiyah dengan dilandasi spirit alquran surat al Ma'un, mengembangkan amal usahanya di berbagai sektor sebagai pembuktian turut ambil bagian mengubah tatanan masyarakat menjadi masyarakat yang lebih maju atau modern. Tidak hanya bidang pendidikan yang digarap tetapi juga mempelopori pendirian panti-panti asuhan, rumah sakit, Bank Perkreditan Rakyat, dan lain-lain

Muhammadiyah sebagai kelompok organisasi masyarakat Islam berusaha menghadirkan gerakan pencerahan untuk memberikan solusi terhadap problematika umat berupa kemiskinan, kebodohan, ketertinggalan, dan persoalan-persoalan lainnya yang bercorak struktural dan kultural. Selain itu, sebagaimana termaktub dalam buku Model Dakwah Pencerahan Berbasis Komunitas yang disampaikan pada Muktamar Muhammadiyah ke 47 tahun 2015, bahwa Muhammadiyah berikhtiar mengembangkan strategi dari revitalisasi (penguatan kembali) ke transformasi (perubahan dinamis) untuk melahirkan amal usaha dan aksi-aksi sosial kemasyarakatan yang memihak kaum dhuafa dan mustadh'afin serta memperkuat civil society (masyarakat madani) bagi kemajuan dan kesejahteraan bangsa (Persyarikatan Muhammadiyah, 2015). Dapat dilihat dari pemikiran tersebut, dakwah yang dilakukan gerakan Muhammadiyah selama ini tidak hanya mengandalkan dakwah bi-lisan berbentuk ceramah tabligh berhadapan dengan massa dan berbentuk lisan serta tulisan, tetapi juga melaksanakan dakwah bil-hal (dakwah dengan tindakan).

Dakwah bil hal secara bahasa merupakan penyatuan dari dua suku kata yang berasal dari Bahasa Arab; yaitu dakwah dan al-hal. Kata 'dakwah' memiliki makna menyeru,memanggil, mengarahkan. Sedangkan secara istilah, arti kata'dakwah'mengandung pengertian:menyeru manusia kepada perilaku kebajikan serta melarang atau menghindar kan mereka dari perbuatan mungkar. Kata 'Walhal'memiliki artis, kenyataan, keadaan, bukti konkrit. Penyatuan dari dua kata di atas,dapat diertikan dengan menyeru atau mengajak dengan menggunakan 'bahasa'perbuatan atau keadaan yang nyata (konkrit). Dakwah dengan cara ini dianggap lebih efektif di bandingkan dakwah dengan perkataan (dakwah bil kalam), sebagaimana pepatah Arab menyatakan; "lisanal-hal afsahu Mion lisan al-maqal”(bahasa perbuatan (teladan yang baik) lebih efektif dari pada bahasa perkataan) (Hakim, 2017). Sementara itu dakwah bil hal menurut Harun al Rasyid adalah keseluruhan upaya mengajak orang secara sendiri-sendiri maupun kelompok untuk mengembangkan diri dan masyarakat dalam rangka mewujudkan tatanan sosial ekonomi dan kebutuhan yang lebih baik menurut tuntunan Islam, yang berarti banyak menekankan pada masalah kemasyarakatan seperti kemiskinan, kebodohan, keterbelakangan dengan wujud amal nyata terhadap sasaran dakwah (Suisyanto, 2002).

Masyarakat mengenal Muhammadiyah selama ini banyak berperan dalam bidang pendidikan, sosial dan kesehatan di perkotaan. Padahal dakwah bil hal yang dilaksanakan Muhammadiyah sudah begitu terencana untuk menyentuh komunitas tertentu, termasuk masyarakat pedesaan. Strategi, pendekatan dan sasaran dakwah gerakan Muhammadiyah memang harus menyentuh beberapa komunitas lapisan masyarakat seperti komunitas atas, komunitas menengah, komunitas bawah, komunitas marjinal, komunitas virtual, komunitas hobi, dan komunitas khusus. Pemetaan sasaran komunitas yang akan dituju oleh gerakan Muhammadiyah ini harus ditindaklanjuti dengan memperhatikan pulau Indonesia sebagai sebuah negara agraris di mana sebagian besar penduduknya berprofesi sebagai petani. Mahmuddin (2013) mengungkapkan bahwa berbicara tentang masyarakat agraris, maka tidak bisa dipisahkan dengan masyarakat desa, sebab sekitar 80\% masyarakat agraris berada di pedesaan, demikian pula masyarakat tradisional. Petani dalam hal ini dimasukkan ke dalam kelompok masyarakat kelas menengah ke bawah (lower middle-class).

Berdasarkan penelitian terdahulu yang berkaitan dengan peran maupun kegiatan dakwah Muhammadiyah pada masyarakat di pedesaan, Rafiq (2016) yang meneliti gerakan dakwah Muhammadiyah di Kabupaten Tapanuli Selatan melalui metode penelitian secara kualitatif menyimpulkan bahwa sistem dakwah yang dibentuk sebagai suatu keseluruhan memiliki fungsi mengubah lingkungan dan metode dakwah yang diterapkan melalui pendekatan kultural lebih sesuai bagi masyarakat yang mayoritas petani dari pada metode dakwah melalui ceramah karena dalam metode ceramah dibutuhkan sejumlah orang, tempat dan waktu yang dapat menimbulkan masalah.

Sementara penelitian Mustanir (2019) menyatakan dakwah dan perkembangan Muhammadiyah dengan penggunaan metode Participatory Rural Appraisal (PRA) sebagai metode perencanaan partisipatif pada perencanaan pembangunan yang dapat digunakan sebagai sarana dakwah mubaligh Muhammadiyah di Desa Carawali Kecamatan Watang Pulu Kabupaten Sidenreng Rappang. Hasil penelitiannya menyimpulkan bahwa metode PRA belum belum dimanfaatkan secara optimal sebagai sarana dakwah oleh mubaligh Muhammadiyah.

Luthfie (2018) sependapat dengan penelitian yang telah disebutkan di atas dalam penelitiannya menganalisis peran Muhammadiyah dalam pembangunan di Desa Plompong. Organisasi Muhammadiyah di desa ini dibentuk dalam rangka memperluas jaringan komunikasi dengan tokoh masyarakat dan aparat setempat. Dari hasil penelitiannya ditunjukkan bahwa harmonisasi dan akses organisasi Muhammadiyah dalam pembangunan desa di Desa Plompong telah mampu diciptakan oleh struktur dan jaringan komunikasi Muhammadiyah.

Untuk itu penelitian ini ingin menyoroti pola komunikasi dalam peran Muhammadiyah sebagai organisasi massa Islam, di pedesaan yang berorientasi pada kegiatan dakwah bil hal. Masyarakat perdesaan ini digolongkan pada kelompok kelas bawah sebagaimana dapat dilihat pada Tabel 1. 
Table 1 Aktivitas Dakwah Bil Hal Persyarikatan Muhammadiyah

\begin{tabular}{llllll}
\hline Kelompok Subyek & Karakteristik & Pendekatan & Segmen & Program & Leading sektor \\
\hline 1. Buruh & Ekonomi rentan; & Strukturalisme & Jenis kelamin, & ·Tablighbil Lisan: & Tarjih,Tabligh, \\
2. Tani & Politik & (Mendorong & Usia (Tua, & ceramah,simulasi & Kader,AMM, Aisyiyah, \\
3. Nelayan & pragmatis; & perubahan & Dewasa, & ·DistribusiZIS & LazisMu,LPCR, \\
4. Pedagang & Budaya sinkretis; & sistem dan & Pemuda, & ·PaketProgramAMM & MPM,Ekonomi, Wakaf, \\
5. Pengrajin & Sosial Komunal; & perilaku) & Remaja) & ·Pembentukan kelompok & \\
\hline
\end{tabular}

Sumber: Model Dakwah Pencerahan Berbasis Komunitas (Persyarikatan Muhammadiyah, 2015)

Menurut Tabel 1 berbagai subyek dalam dakwah bil hal tidak membatasi segmen bagi para pelaku dakwah untuk melakukan pendekatan strukturalis yakni mendorong perubahan sistem dan perilaku dengan berbagai program yang sudah terencana seperti tabligh bil lisan berupa ceramah dan simulasi serta distribusi ZIS. Kelompok kelas bawah dapat diartikan sebagai kelompok yang masih memiliki pekerjaan atau sumber penghasilan yang rutin namun rentan secara ekonomi karena minimnya penghasilan yang mereka dapatkan untuk memenuhi kebutuhan hidup sehari-hari. Artinya,setiap saat kelompok ini bisa jatuh dalam kemiskinan. Masyarakat yang termasuk dalam kategori kelompok bawah ini antara lain buruh, buruh tani, nelayan, pedagang kecil, pengrajin dan juga pegawai rendahan (Persyarikatan Muhammadiyah, 2015).

Masyarakat agraris sebagai objek dalam penelitian ini adalah masyarakat pedesaan yang bermata pencaharian sebagai petani di Kabupaten Bandung yang dipilih dengan sengaja berdasarkan alasan bahwa daerah tersebut merupakan salah satu sentra kegiatan pertanian di Jawa Barat, yang berada dalam ruang lingkup kegiatan dakwah Pimpinan Daerah Muhammadiyah. Pemilihan daerah sampel dipertimbangkan menurut data BPS tahun 2018 yang menunjukkan bahwa di Kecamatan Pangalengan terdapat 710 penduduk yang bermata pencaharian sebagai petani palawija dan hortikultura. Kegiatan dakwah bil hal Muhammadiyah di Kecamatan Pangalengan berkantor di desa Pulosari. Penelitian ini dimaksudkan agar diketahui secara jelas mengenai pola komunikasi Muhammadiyah dalam pelaksanaan dakwah bil hal pada masyarakat agraris sebagai representasi kegiatan dakwah yang berguna sebagai informasi dan referensi bagi para Pimpinan Daerah Muhammadiyah di wilayah lainnya.

\section{METODE PENELITIAN}

Penelitian ini menggunakan metodologi deskriptif kualitatif seperti yang diungkapkan oleh Sudaryono yang bertujuan untuk menjelaskan dan menggambarkan keadaan atau fenomena dari suatu populasi sebagai objek penelitian yang dalam hal ini adalah Pimpinan Daerah Muhammadiyah (Nugrahadi, 2019).

Peneliti memperoleh data primer melalui wawancara mendalam dengan sumber informasi atau narasumber dan hasil observasi lapangan terhadap ketua Pimpinan Daerah Muhammadiyah serta 30 orang petani yang dipilih dengan alasan pengetahuan petani pada Muhammadiyah. Sedangkan data sekunder penulis dapatkan melalui dokumentasi dan catatan yang berasal dari arsip-arsip,referensi buku,dan jurnal yang berkaitan dengan penelitian dimaksud.

Penelitian ini dilakukan di Kabupaten Bandung dengan mengambil lokasi sampel di Kecamatan yang memiliki Kantor Cabang Muhammadiyah yang berada di bawah koordinasi Pimpinan Daerah Muhammadiyah Kabupaten Bandung. narasumber dalam penelitian ini ditentukan dengan menggunakan purposive sampling terdiri atas Ketua Pimpinan Daerah Muhammadiyah (PDM) Kabupaten Bandung, anggota Pimpinan Cabang Muhammadiyah (PCM) Pangalengan dan Kertasari, tokoh masyarakat, dan petani berdasarkan kriteria-kriteria tertentu yang telah dipertimbangkan seperti yang telah disebutkan meliputi pengetahuan tentang Muhammadiyah baik secara organisasi maupun program-program. Hal ini sesuai dengan pendapat Kriyantono bahwa kriteria narasumber dipertimbangkan agar dapat mendukung tujuan penelitian (Kriyantono, 2010).

Penelitian ini menggunakan teknik analisis data model interaktif Miles dan Huberman yaitu mereduksi data wawancara, menyajikan data dalam bentuk kutipan, dan menarik kesimpulan beberapa pola komunikasi yang dilakukan oleh pengurus persyarikatan Muhammadiyah di Kabupaten Bandung (Sugiyono, 2007). Hasil penelitian dari penarikan kesimpulan diuji validitasnya dengan menggunakan triangulasi sumber data dengan cara mengecek ulang derajat kepercayaan suatu informasi yang diperoleh dari berbagai sumber (Kriyantono, 2010). Dengan demikian hasil penelitian ini dikatakan valid setelah diperoleh beberapa pandangan selain dari peneliti yaitu pandangan dari ketua dan pimpinan inti PDM Kabupaten Bandung, ketua dan pimpinan inti PCM, serta masyarakat petani baik yang tergabung sebagai anggota maupun bukan anggota Muhammadiyah atau sebatas simpatisan.

\section{HASIL DAN PEMBAHASAN}

Dakwah Muhammadiyah ditinjau dari perannya terhadap masyarakat agraris secara khusus bertujuan untuk menghasilkan informasi yang berguna untuk mengelola program dakwah. Ada atau tidaknya peran itu akan memberikan 
uraian mengenai faktor-faktor yang menentukan persepsi atas peran tersebut. Dengan demikian hasil temuan pada penelitian ini akan menjadi sumber informasi untuk dapat menafsirkan efektivitas kegiatan sebagai pola dakwah pada suatu komunitas di wilayah agraris.

Pimpinan Daerah Muhammadiyah (PDM) sebagai salah satu organisasi massa di Kabupaten Bandung dalam programnya menargetkan empat pilar sebagaimana program dakwah bil hal yang diamanatkan yaitu bidang pendidikan, kesehatan, sosial, dan ekonomi. Keberhasilan dan kegagalan program ini sangat ditentukan oleh upaya ketua dan anggota PCM serta PDM Kabupaten Bandung. Penelitian ini ingin melihat bagaimana pola komunikasi yang dibangun antara organisasi Muhammadiyah dengan para petani di Kabupaten Bandung dalam pelaksanaan program dakwah bil hal.

Konsep pola komunikasi yang dimaksud dalam penelitian ini berpijak pada pendapat Djamarah (2004), yaitu bentuk atau pola hubungan dua orang atau lebih dalam proses pengiriman dan penerimaan cara yang tepat sehingga pesan yang dimaksud dapat dipahami. Sedangkan Sanityastuti, Wijayanti, dan Kunandar (2015) merumuskan pola komunikasi berdasar pendapat Katz dan Kahn sebagai suatu identifikasi untuk mengakses tingkah laku komunikasi dalam suatu sistem karena pola komunikasi menyediakan konteks atau ruang untuk memahami tingkah laku yang spesifik. Pola komunikasi disesuaikan dengan kondisi anggota dan komunikasi yang ada saat berinteraksi dengan lingkungannya. Pola ini bila dihubungkan dengan figure komunikator, pesan,dan media akan menjadi suatu rangkaian yang beragam dan berkembang.

Sementara Nurudin (2004) mengutip pendapat Joseph A. Devito yang menyatakan bahwa pola komunikasi terbagi menjadi empat yaitu komunikasi antarpribadi, komunikasi kelompok kecil, komunikasi publik dan komunikasi massa. Dengan pendekatan teori yang ditawarkan Devito tentang pola komunikasi tersebut, peneliti berusaha mendeskripsikan hubungan yang terjalin antara PDM Kabupaten Bandung dengan masyarakat agraris di wilayah tersebut.

\section{A. Pola Komunikasi Antarpribadi}

Komunikasi Antarpribadi (komunikasi interpersonal)merupakan komunikasi yang terjalin antara dua orang secara langsung. Berger, Dainton dan Stafford mengatakan bahwa konteks komunikasi antarpribadi banyak membahas tentang bagaimana suatu hubungan dimulai, bagaimana mempertahankan hubungan, dan bagaimana munculnya keretakan dalam hubungan tersebut (West \& Turner, 2014). Menurut pengamatan peneliti pelaksanaan dakwah bil hal Muhammadiyah terhadap petani di Kabupaten Bandung, berawal dari keterampilan para pengurus mengadakan komunikasi antarpribadi. Berikut ini pemaparan narasumber:

"Selain itu, program pengajian sangat rutin dari setiap $R W$ rutin ada sehingga full senin-jumat pengajian bergilir dari setiap RW nya. Programnya informal, karena diskusi langsung dengan kelompok tani menyelesaikan permasalahan petani, selain itu mitra kerja saja dan dibina oleh saya. Kajian dalam seminggu ada lima kali, kemudian dakwah di bidang pendidikan dengan membangun SDIK (sekolah dasar islam kreatif) Muhammadiyah, dengan harapan membuat kreatif dan membangun jiwa kewirausahaan sejak dini. Masyarakat tak mengenal organisasi, sehingga lewat dakwah ekonomi membawa manfaat dan solusi, ” (H. Usep, wawancara pribadi, 21 November 2019).

Pernyataan di atas menjelaskan peran Muhammadiyah dalam dakwah bil hal melalui pertanian, perdagangan, dan perekonomian dapat diterima langsung oleh masyarakat petani. H. Usep sebagai ketua PDM Kabupaten Bandung secara intens mengawali dakwah bil hal dengan melakukan komunikasi antarpribadi. Menurut Devito (1997), komunikasi antarpribadi atau interpersonal yang efektif memiliki lima aspek yaitu keterbukaan (opennes), sikap positif (positiveness), empati (emphaty), sikap mendukung (supportiveness), dan kesetaraan/kesamaan (equality). Kelima aspek ini sudah dilakukan oleh ketua PDM pada wilayah Kecamatan Pangalengan dan Kertasari terlihat dari pernyataan-pernyataan narasumber di bawah ini.

Sikap keterbukaan disampaikan oleh Ujang sebagai berikut.

"Pak Usep sangat terbuka mendengarkan keluhan, sering diskusi juga. Selain itu pengurus PCM juga selalu mendengar keluhan anggota, jadi saat pengajian selesai juga suka ngobrol lagi, "(Ujang, wawancara pribadi, 21 November 2019).

Pernyataan di atas ditambahkan pula oleh Tomo tentang sikap empati dan kesetaran.

"Pak Usep selalu mendengarkan semua keluhan anggota, jika beliau pribadi dapat membantu langsung. Langsung dibantu, namun jika harus didiskusikan di forum pun pasti dibahas di forum. Saya sendiri dengan beliau karena sudah dekat jadi kalau ada apa-apa langsung telepon saja," (Tomo, wawancara pribadi, 20 November 2019).

Sementara itu berbicara mengenai peran supportiveness ketua PDM Kabupaten Bandung sebagai berikut.

"Peran Pak Usep sangat berdampak terhadap kehidupan desa Pangalengan, sekarang dengan membangun sekolah dasar itu, beliau mewakafkan tanah dengan membangun sekolah dan memberikan pendidikan gratis. Itu sangat berdampak kepada kehidupan masyarakat, selain itu dengan bermitra dengan petani. Membantu 
dari segi modal, kemudian hasil pertaniannya pun dibantu pemasarannya. Selain itu dapat menjadi panutan, jika ingin diskusi atau berkeluh kesah dapat menjadi tempat, dan jika beliau dapat memberikan solusi dan membantu secara langsung yah pasti dibantu," (Ilit, wawancara pribadi, 21 November 2019).

Mamat menambahkan tentang sikap positif ini.

"Sangat terasa dampak positifnya dalam setiap hal, seperti saya juga dulu kan ikut dengan pak Usep dalam bertani. Diberikan modal dan edukasi mengenai pertanian, dan akhirnya sudah bisa sendiri jadi membuka usaha sendiri. Sering diskusi mengenai semua hal, terutama dakwah dalam keagamaan pasti ikut serta rutin dalam pengajian," (Mamat, wawancara pribadi, 23 November 2019).

Masih dalam hal sikap positif dan sokongan PCM terhadap petani.

"Saling percaya, karena pak Usep sempat memberikan modal usaha kepada petani. Setelah itu dibina untuk menjadi petani yang mandiri.Apapun masalahnya pasti berunding, saling membantu. Saling menolong meski bukan dengan anggota Muhammadiyah," (Tomo, wawancara pribadi, 20 November 2019).

Tanggapan dari petani atau narasumber lain di Pangalengan yaitu Agus, Mana, Jajang Daman, Sukarya dan Idih, semua tanggapan yang disampaikan mereka tidak berbeda jauh dengan yang disampaikan di atas. Pola komunikasi antarpribadi yang dibangun PDM Kabupaten Bandung terbukti efektif menumbuhkan kepercayaan dari masyarakat petani sehingga peran dan sosok figurnya sangat dihargai. Melalui dakwahnya di bidang ekonomi yang bermitra dengan petani, pengajian rutin keagamaan yang selalu dilaksanakan, serta adanya SDIK yang baru dibangun semakin menunjukkan bahwa ketua PDM Kabupaten Bandung berdakwah dengan tulus dan fokus berdakwah di bidang sosial, ekonomi, dan pendidikan.

\section{B. Pola Komunikasi Kelompok}

Berangkat dari pola komunikasi antarpribadi, pola komunikasi yang dibangun Muhammadiyah dalam pelaksanaan dakwah bil hal kepada petani di Kabupaten Bandung khususnya di Kecamatan Pangalengan dan Kertasari adalah pola komunikasi kelompok. Kelompok yang dimaksud di sini adalah kelompok kecil atau small group. Terdiri dari sekumpulan orang yang memiliki tujuan yang sama. Merujuk pada pengertian ini, komunikasi kelompok dapat bermakna interaksi antara anggota kelompok yang boleh jadi bersifat kohesif, sinergi dalam pemecahan masalah, dan berkontribusi dalam mencapai tujuan. Brilhart, Galanes dan Adams bahkan menggarisbawahi fakta bahwa kelompok kecil ada untuk memenuhi kebutuhan tertentu (West \& Turner, 2014).

Menurut narasumber H. Usep, program dakwah bil hal PDM Kabupaten Bandung yaitu programnya melalui kelompok tani. Selain itu membina 270 RW dengan perwakilan 2-3 orang setiap RWnya. Melalui program tersebut, Pak Usep menyebarkan dakwah melalui petani binaannya, sehingga dakwahnya cepat tersampaikan meskipun Muhammadiyah itu tergolong baru di Kecamatan Kertasari dan Kecamatan Pangalengan. Baru sebentar berdiri namun sudah membangun kepercayaan masyarakat akan adanya Muhammadiyah karena dakwahnya melalui pertanian, perdagangan, perekonomian sehingga masuknya lebih cepat dan diterimanya cepat. Hal tersebut dipengaruhi karena kuatnya dakwah di bidang ekonomi dan bahwa Muhammadiyah dapat membantu mensejahterakan petani dan memberikan solusi. Jadi tidak hanya membangun tauhidnya .

Kehadiran Muhammadiyah di tengah masyarakat agraris ini pada awalnya tidak mudah. Untuk mendapat respons dari masyarakat, PDM Kabupaten Bandung melakukan pendekatan pada kelompok tani melalui jalur informal. Dibentuknya kelompok-kelompok tani binaan dari PCM Pangalengan dan PCM Kertasari ini menurut H. Usep.

"Untuk membangun mental wirausaha, mental kreatif sejak dini, dan mendidik petani untuk menjadi warga Muhammadiyah yang terbiasa memberi dari pada meminta, karena tangan di atas lebih baik dari pada tangan di bawah. Selain itu untuk kaum perempuan warga petani diarahkan menjadi NA dan Aisyiyah juga dibina untuk menjadi wirausaha, sehingga saat membuat kegiatan, membuat karya jadi tidak meminta-minta. Agar dapat mandiri, karena yang harus dibangun dengan kuat itu di bidang ekonominya. Sejauh ini semua programnya sudah berjalan, dari pembinaan petani, sekolah SDIT, wirausaha di NA dan Aisyiyah. Cara kerja yang saya tanamkan di Muhammadiyah yaitu Kerja Ikhlas, Cerdas, Tuntas, Jujur dan Amanah," (H. Usep, wawancara pribadi, 21 November 2019).

Pendapat ini ditambahkan oleh Tomo yang memperlihatkan terjalinnya komunikasi kelompok yang ditandai kerja sama dan saling percaya di antara para petani binaan dengan PCM.

"Jika ada apapun kami mendengarkan keluh kesah anggota, contohnya ada yang mau kuliah aja kami bantu karena tidak ada biaya, jadi kami bantu untuk memberikan rekomendasi agar ada bantuan dari pihak wilayah. Semua kami tampung keluh kesah anggota dan jika dapat memberikan solusi yah kami bantu. Saling percaya, untuk dari program pak Usep aja. Itu kan kemitraan, sampai Kertasari pun terasa. Seperti memberikan bibit jeruk untuk ditanam dan saling membantu untuk pemasarannya," (Tomo, wawancara pribadi, 20 November 2019). 
Selain itu beberapa tahapan yang bisa dirangkum dari hasil wawancara dengan beberapa narasumber untuk menjelaskan pola komunikasi kelompok yang dibangun tersebut adalah:

1. Memberikan penjelasan yang logis tentang Muhammadiyah bahwa Muhammadiyah adalah organisasi massa yang sama dengan tarka atau karang taruna

2. Memberi manfaat solusi, melalui hubungan ekonomi menjadi dekat untuk merepresentasikan kehebatan dakwah bidang ekonomi

3. Menjembatani kelompok tani dengan perusahaan

4. Membangun akidah walaupun tidak mudah

5. Membenahi umat Islam yang terkontaminasi melalui bisnis yang cerdas dengan memfungsikan akal pikirannya.

6. Membantu menyelesaikan permasalahan pendidikan bagi keluarga yang mendapat kesulitan melanjutkan pendidikan.

\section{Pola Komunikasi Publik}

Sebagaimana ormas Islam lainnya, program dakwah Muhammadiyah juga dilakukan secara umum, seperti melaksanakan ceramah keagamaan dari mesjid ke mesjid, dan bergiliran dari rumah ke rumah yang dihadiri oleh banyak peserta atau khalayak. Dalam ilmu komunikasi, pola ini dikenal sebagai pola komunikasi publik atau komunikasi kelompok-besar (large-group communication) sebagaimana diistilahkan oleh para pakar komunikasi.

Pada saat berbicara di hadapan public biasanya penceramah telah mempersiapkan betul materi yang akan dibahas pada forum pengajian tersebut. Biasanya para pembicara memiliki tiga tujuan utama dalam benak mereka: memberi informasi, menghibur, dan membujuk. Tujuan terakhir persuasi adalah inti dari komunikasi retorika (West \& Turner, 2014).

Pengajian rutin yang dilaksanakan oleh PDM Kabupaten Bandung melalui koordinasi dengan PCM, tentu saja memiliki tujuan. Terjadinya perubahan perilaku masyarakat agar sesuai dengan ajaran Islam merupakan salah satu keberhasilan penceramah dalam mencapai tujuannya. Pendekatan persuasif lebih diutamakan untuk meraih animo masyarakat petani, sehingga pengajian rutin yang dilakukan PCM- PCM di Kabupaten Bandung tidak hanya berlangsung formal, tetapi dilanjutkan dengan diskusi informal. Seperti yang dituturkan seorang peserta pengajian.

"Program pengajian rutin dari setiap RW berjalan rutin mulai hari Senin sampai hari Jumat. Pengajian bergilir dari setiap RW-nya. Programnya informal, karena dilanjutkan dengan diskusi langsung dengan kelompok tani dan menyelesaikan permasalahan petani. Bentuk pembinaan kepada para petani adalah dengan mengundang mereka dalam pengajian rutin tersebut. Kajian dilaksanakan lima kali dalam seminggu," (Peserta Pengajian, wawancara pribadi, 19 November 2019).

H. Usep menjelaskan bahwa.

"membangun akidah itu tidak mudah. Cita-cita Muhammadiyah adalah mewujudkan masyarakat Islam yang sebenar benarnya. Pelaksanaan pengajian itu dalam rangka membenahi umat Islam yang terkontaminasi. Mendorong bisnis yang cerdas dengan menggunakan akal pikirannya untuk difungsikan. Bagaimana kalimat syahadat, dan kalimat rodhitu billahi rabba dan seterusnya ketika dihadapkan pada kenyataan, ternyata hanya symbol-simbol saja. Islam agama tauhid seperti yang termaktub dalam QS Al Bayyinah (98) ayat 5 perlu diluruskan. Ternyata kemusyrikan masih merajalela, arena belum mengerti makna solat. Inna solata tanhaa anil fahsyaa_i wal munkar. Artinya solat itu mencegah perbuatan keji dan munkar," (H. Usep, wawancara pribadi, 21 November 2019).

Ujang menambahkan bahwa:

"Cara dakwah dengan cara pengajian, membangun sekolah, membangun panti asuhan, banyak ilmu yang saya dapat dari pak Usep mengenai agama, sosial, politik, dan membuka pola pikir saya. Mengikuti berbagai macam kegiatan yang PCM laksanakan seperti contohnya di pemberdayaan ekonomi, karena kebanyakan potensi berupa pertanian dengan membina petani yang dikasih modal, hasil pertanian di tampung dan dijual, program peternakan sapi investasi dan hasilnya dibagi dua. Selain itu pengajian rutin juga mengikuti," (Ujang Sodiqin, wawancara pribadi, 17 November 2019).

Narasumber lain juga mengungkapkan bahwa kehadiran Muhammadiyah di daerah Pangalengan ini adalah untuk membasmi TBC yaitu Takhayul Bid'ah dan Khurafat. Pelaksanaan dakwah kepada khalayak/publik tidak hanya di masjid. Mereka berpendapat bahwa pengajian juga secara rutin dilakukan pada saat di kebun. Sejauh ini metode ceramah/dakwah yang dilakukan di kebun tersebut bersifat interaktif dengan menggunakan metode diskusi. Isi pembahasan tidak hanya berkisar pada masalah agama Islam dan kemuhammadiyahan tetapi juga masalah pertanian, ekonomi, dan pendidikan. 


\section{Pola Komunikasi Massa}

Konsep terakhir dari Devito (1997) yang berkaitan dengan fokus penelitian ini adalah pola komunikasi massa. Baran dan Davis (2015) mengisyaratkan, ketika sebuah organisasi menggunakan teknologi sebagai sebuah media untuk berkomunikasi dengan khalayak yang besar, maka akan terjadi komunikasi massa. Sebagaimana akselerasi terjadi pada perkembangan teknologi saat ini, demikian pula terjadi pada komunikasi massa. Terjadinya konvergensi berupa hilangnya batas perbedaan antara media disebabkan pula oleh teknologi.

Menurut Cooper, konvergensi tidak akan terjadi sampai anda memiliki segala sesuatu dalam bentuk digital yaitu ketika konsumen dapat dengan mudah menggunakannya pada semua bentuk peralatan yang berbeda (Baran \& Davis, 2015). Seiring dengan konvergensi media, komunikasi massa tidak hanya terbatas berupa media elektronik seperti televisi dan radio, serta media cetak seperti surat kabar, majalah, tabloid. Media kekinian adalah media daring seperti Youtube, Facebook, Instagram, Twitter, dan WhatsApp. PDM Kabupaten Bandung melalui PCM Pangalengan dalam membangun pola komunikasi dengan masyarakat petani, juga memanfaatkan media komunikasi massa daring ini yaitu penggunaan WhatsApp. Konten dari media ini bisa berupa informasi keagamaan, berisi informasi untuk mengadakan pertemuan membahas perkembangan di lapangan, juga informasi tentang program PCM.

“...pengurus PCM dan PDM Terbuka dalam komunikasi, jika ada info atau ada sesuatu bisa komunikasi melalui WhatsApp.. Setiap ada program juga terbuka, suka diundang...” (Ujang Sodiqin, wawancara pribadi, 17 November 2019).

Munculnya berbagai aplikasi pintar dari media komunikasi daring selain WhatsApp ini tentu saja sangat bermanfaat karena dapat memperkaya wawasan informasi, khususnya bidang pertanian dan juga sebagai alat branding dan marketing produk pertanian, tetapi belum optimal dimanfaatkan baik oleh PDM maupun masyarakat petani.

Dakwah bil hal yang dilaksanakan telah meningkatkan partisipasi masyarakat terhadap Muhammadiyah di Kabupaten Bandung. Meski pada dasarnya peningkatan tersebut karena adanya peran kegiatan yang dilakukan oleh Pimpinan Daerah Muhammadiyah sebagai sesuatu yang dibutuhkan oleh para petani, tetapi harus juga diketahui oleh para pendakwah bahwa pola komunikasi antar pribadi, komunikasi kelompok, komunikasi publik dan komunikasi massa merupakan faktor penting yang tidak terpisahkan dari keberhasilan pelaksanaan kegiatan dakwah bil hal yang dilakukan oleh sebuah organisasi masyarakat islam.

\section{KESIMPULAN}

Dari keseluruhan pembahasan di atas, peneliti menyimpulkan bahwa ada empat pola Komunikasi yang dibangun oleh Muhammadiyah dalam pelaksanaan dakwah bil hal kepada para petani di daerah Kabupaten Bandung. Pertama, pola komunikasi antarpribadi yaitu pola komunikasi yang digunakan untuk penyampaian pesan dakwah bil hal secara langsung dan tatap muka antara Muhammadiyah dengan masyarakat petani binaannya. Sikap keterbukaan (opennes), sikap positif (positiveness), empati (emphaty), sikap mendukung (supportiveness), dan kesetaraan/kesamaan (equality) yang ditunjukkan oleh PDM Kabupaten Bandung mampu menarik simpati petani untuk bangkit dan tergerak meningkatkan perekonomian keluarganya. Kedua, pola komunikasi kelompok yaitu pola komunikasi yang dilakukan secara kelompok yang bersifat tatap muka. Dalam pelaksanaan dakwah bil hal, PDM Kabupaten Bandung melalui PCM Pangalengan dan Kertasari membina dan membimbing kelompok-kelompok tani untuk memberikan jalan bagi terwujudnya cita-cita yang diharapkan petani. Para petani didorong untuk membuat kemajuan perekonomian agar dapat bersaing dengan daerah lain, saling berdiskusi mencari solusi hingga pada tataran teknisnya. Ketiga, pola komunikasi publik yaitu pola Komunikasi yang dilakukan oleh seorang pembicara dengan sejumlah besar orang atau masyarakat umum. Pada pola ini salah satu PCM yakni di Kecamatan Pangalengan memanfaatkan masjid sebagai tempat kajian rutin untuk menyampaikan pesan dakwah kepada khalayak ramai dan di tempat umum, sehingga dapat dijangkau oleh siapa saja yang mendengarnya. Keempat, pola komunikasi massa yaitu pola komunikasi dengan menggunakan media massa baik itu media elektronik, media cetak, dan media daring. Dalam dakwah, ini media yang digunakan adalah WhatsApp.

Dari keempat pola tersebut, peneliti melihat bahwa dakwah bil hal dengan pola komunikasi antarpribadi dan komunikasi kelompok merupakan pola yang paling efektif dilakukan PDM Kabupaten Bandung karena dapat menyentuh langsung kebutuhan dari masyarakat agraris di daerah ini. Melalui pola komunikasi antarpribadi dan komunikasi kelompok ini dapat digali masukan, untuk mengetahui permasalahan dan hambatan di lapangan. Kedekatan yang dibangun secara personal oleh ketua PDM selain menumbuhkan kepercayaan masyarakat terhadap figur pribadi juga terhadap eksistensi Muhammadiyah sehingga memudahkan PDM untuk menggulirkan program dakwah bil hal. Adapun dalam pola komunikasi publik peneliti beranggapan kurang efektif mengingat banyaknya khalayak yang terlibat, sedangkan pada pola komunikasi massa, penguasaan media baru belum dimanfaatkan secara optimal baik oleh PDM Kabupaten Bandung maupun masyarakat petani, sehingga perlu ada sosialisasi dan literasi media digital. 


\section{DAFTAR PUSTAKA}

[1] Baran, S. J., \& Davis, D. K. (2015). Teori Komunikasi Massa - Dasar, Pergolakan, dan Masa Depan. Salemba Humanika.

[2] Devito. (1997). Komunikasi Antar Manusia. Book Profesional.

[3] Djamarah, S. B. (2004). Pola Komunikasi Orang Tua dan Anak Dalam Keluarga. PT. Aneka Cipta.

[4] Hakim, R. (2017). Dakwah Bil Hal: Implementasi Nilai Amanah dalam Organisasi Pengelola Zakat untuk Mengurangi Kesenjangan dan Kemiskinan. IQTISHODIA: Jurnal Ekonomi Syariah, 02(02), 42-63.

[5] Kriyantono, R. (2010). Tekhnik Praktis Riset Komunikasi: disertai contoh praktis riset media, public relations, advertising, komunikasi organisasi, komunikasi pemasaran. Kencana Prenada Media Group.

[6] Luthfie, M. (2018). Jaringan Komunikasi Organisasi Masyarakat Dalam Pembangunan. Jurnal Sosial Humaniora, 9(1), 17. https://doi.org/10.30997/jsh.v9i1.1376

[7] Mahmuddin. (2013). Strategi Dakwah Terhadap Masyarakat Agraris. Jurnal Dakwah Tabligh, 14, 101-113.

[8] Mulyadi, M. (2015). Perubahan Sosial Masyarakat Agraris ke Masyarakat Industri dalam Pembangunan Masyarakat di Kecamatan Tamalate Kota Makassar. Jurnal Bina Praja, 07(04), 311-321. https://doi.org/10.21787/ jbp.07.2015.311-321

[9] Mustanir, A. (2019). Participatory Rural Appraisal (PRA) Sebagai Sarana Dakwah Muhammadiyah Pada Perencanaan Pembangunan di Kabupaten Sidenreng Rappang. https://doi.org/10.13140/RG.2.2.21413.35043

[10] Nugrahadi, A. (2019). Uncertainty Reduction Theory dalam Pola Komunikasi Pemain dan Pelatih Sepakbola Usia Dini di PFA ( Pasoepati Football Academy ). CHANNEL Jurnal Komunikasi, 7(2), 137-146. https://doi.org/http:// dx.doi.org/10.12928/channel.v7i2.13611

[11] Nurudin. (2004). Sistem Komunikasi Indonesia. Raja Grafindo Persada.

[12] Persyarikatan Muhammadiyah. (2015). Model Dakwah Pencerahan Berbasis Komunitas.

[13] Rafiq, M. (2016). Metode Dakwah Muhammadiyah di Kabupaten Tapanuli Selatan. Tazkir, 02(1), 31-50.

[14] Sanityastuti, M. S., Wijayanti, Y. T., \& Kunandar, A. (2015). Pola Komunikasi Keluarga dalam Membangun Akhlakul Karimah. CHANNEL Jurnal Komunikasi, 3(2), 113-122. https://doi.org/10.12928/channel.v3i2.3278

[15] Sugiyono. (2007). Metode Penelitian Kuantitatif Kualitatif dan R\&D. Alfabeta.

[16] Suisyanto. (2002). DAKWAH BIL-HAL (Suatu Upaya Menumbuhkan Kesadaran dan Mengembangkan Kemampuan Jamaah ). Jurnal Aplikasi Ilmu-Ilmu Agama, III(2), 182-192.

[17] West, R., \& Turner, L. H. (2014). Pengantar Teori Komunikasi, Analisis dan Aplikasi. Salemba Humanika.

[18] Yusra, N. (2018). Muhammadiyah: Gerakan Pembaharuan Pendidikan Islam. POTENSIA: Jurnal Kependidikan Islam, 4(1), 103. https://doi.org/10.24014/potensia.v4i1.5269. 